\title{
Effect of Chemical Treatments on the Physicochemical and Tensile Properties of Cow Hair Fibre for Low Load Bearing Composites Development
}

\author{
Isiaka Oluwole Oladele ${ }^{1,3, *}$, Jimmy Lolu Olajide ${ }^{1,2}$, Adekunle Sulaiman Ogunbadejo ${ }^{1}$ \\ ${ }^{1}$ Department of Metallurgical and Materials Engineering, Federal University of Technology Akure, Akure, Nigeria \\ ${ }^{2}$ Department of Mechanical Engineering, Elizade University Ilara-Mokin, Ilara-Mokin, Nigeria \\ ${ }^{3}$ African Materials Science and Engineering Network (AMSEN) a Carnegie-IAS (RISE) Network

\section{Email address:} \\ wolesuccess2000@yahoo.com (I. O. Oladele),jimmy.olajide@elizadeuniversity.edu.ng (J. L. Olajide), \\ adekunleogunbadejo@gmail.com (A. S. Ogunbadejo)
}

\section{To cite this article:}

Isiaka Oluwole Oladele, Jimmy Lolu Olajide, Adekunle Sulaiman Ogunbadejo. Effect of Chemical Treatments on the Physicochemical and Tensile Properties of Cow Hair Fibre for Low Load Bearing Composites Development. International Journal of Materials Science and Applications. Vol. 4, No. 3, 2015, pp. 189-197. doi: 10.11648/j.ijmsa.20150403.16

\begin{abstract}
This research has investigated the influence of $\mathrm{H}_{2} \mathrm{O}_{2}, \mathrm{KOH}$ and $\mathrm{NaOH}$ treatments on the physicochemical and tensile properties of cow hair fibres for composites applications. The chemical treatments for this present study were prepared with predetermined molar concentrations of $0.10,0.15$ and $0.2 \mathrm{M}$ respectively. The physicochemical properties of the cow hair fibres were established using proximate analysis and the tensile properties of the fibres were evaluated with the aid of an Instron universal testing machine. From the results of the proximate analysis, it was observed that, with increase in the concentration of the $\mathrm{H}_{2} \mathrm{O}_{2}$ treatment there was increase in the crude protein and moisture contents and decrease in the ash content of the fibres. However, the $\mathrm{KOH}$ and $\mathrm{NaOH}$ treatments showed an opposite trend. Also, from the tensile test results, it was observed that the chemical treatments aided the enhancement of ultimate tensile and yield strengths of the fibres in comparison with the untreated fibres while tensile strain at break was enhanced by 0.1 and $0.2 \mathrm{M}$ of $\mathrm{KOH}$ as well as $0.2 \mathrm{M}$ of $\mathrm{NaOH}$ treatments. The results of this research have shown that proper chemical treatment can enhance the properties of cow hair fibres for composites applications.
\end{abstract}

Keywords: Animal Fibre, Alkaline and Oxidative Treatments, Physicochemical Constituents, Mechanical Behaviour, Composite Applications

\section{Introduction}

Nowadays, topical advancements in materials processing techniques have efficaciously occasioned in a drastic change in the development of novel engineering materials [1]. Contemporary materials processing routes such as, laser surface melting, electric discharge machining, chemical vapour deposition, thin film technology, and nanotechnology have immensely revolutionized the types of engineering materials emerging from the laboratories of materials scientists and engineers worldwide [2-5]. These new materials offer a broad spectrum of advantages such as aesthetics, low density, biomimicry, non-toxicity and topnotch performance under the harshest service environments be it acidic, basic, and cryogenic or elevated temperatures [6-10]. However, most of these processing techniques are unbearably extortionate, environmentally hazardous and are not relatively available to materials scientists and engineers globally [11].

Albeit, some researchers in the developed countries have been able to establish that the shortcomings concomitant with these new materials are overridden by their fundamental applications and unique functionalities during service life [12]. Quite the opposite, researchers from the developing countries who stalwartly believed that these shortcomings can be progressively vanquished are now congregating their ingenious research efforts in seeking alternatives solutions to develop renewable, sustainable, cost effective, biodegradable, and highly functional engineering materials [15-17]. This mounting convergence in their research efforts has culminated in the proliferation of published research articles on the potential applications of natural fibres, dispersoids and 
particulates as the reinforcing phase in composites, instead of utilizing orthodox synthetic materials such as kevlar, glass, carbon and aramid fibres [18-21].

Hitherto, bulk of the works of materials scientists on natural fibres for composites development has been intensive on vegetal fibres and this has irrefutably yielded in very few literatures available on animal fibres. In fact, these very few literatures available on animal fibres primarily focused on their potential applications in the civil and textile industries [22-25]. Animal fibres include feather, hair, wool and silk which are gotten from animals such as chickens, turkeys, spiders, llamas, alpaca, dogs, horses, rabbits and cows [26]. This present study lays its emphasis on cow hair fibre. Cow hair is gotten from the skin of cows and is made up of keratin protein like most other animal hair fibres which accounts for their engineering properties [27,28]. Oladele et al (2014) reported in their work that the mechanical behavior of cow hair fibre-reinforced high density polyethylene polymer matrix composite under tensile and flexural loadings was improved with random orientation of short cow hair fibres dispersed in the matrix [29]. Another investigation carried out by Oladele et al (2015) also revealed that appropriate chemical treatment on the cow hair fibre prior the composites development, was able to enhance the mechanical behavior of cow hair fibre-reinforced high density polyethylene polymer matrix composites under flexural loading [30].

Despite the fact, that natural fibres from both plants and animals possess some atypical integral advantages over synthetic fibres, such as low energy consumption, carbon dioxide sequestration during materials processing, ecofriendliness, relative availability and cost effectiveness [31], they have also been documented to have high susceptibility to microbial degradation, high moisture absorption, weak interfacial adhesion and poor wettability between the matrix materials and the reinforcing fibres [32]. Nevertheless, studies of researchers have revealed that these discouraging drawbacks can be moderated with the appropriate chemical treatments [33]. M. S. Huda et al (2013) used sodium hydroxide, $10 \%$ maleinized polybutadiene rubber, and a silane-coupling agent to treat fibres of poultry feathers and documented an improvement on thermal performance of fibres and the mechanical properties of the composite developed [34]. Also, according to Lakshmanan (2014) the influence of various chemical treatments such as thioglycollic acid reduction, sulphytolysis, formic acid, morpholine, $\mathrm{NaOH}$ and protease enzyme treatment on Angora rabbit fibres was able to improve the physicochemical, mechanical and morphological properties of the fibres [35].This present study has investigated the influence of $\mathrm{H}_{2} \mathrm{O}_{2}, \mathrm{KOH}$ and $\mathrm{NaOH}$ treatments on cow hair fibres.

The underlying impetus that stimulated the selection of cow hair for this research is the relative abundance of cow hair in Nigeria [36, 37]. According to a report by GEMS (Growth and Employment in States) about 7 million cattle are slaughtered annually in Nigeria and the hair is getting rid of by singeing since a lot of people consume the skins of cows in Nigeria [38-40]. This act of unconscious waste and environmental pollution caused by the burning of the cow hair can be curbed if the cow hair fibres are channeled towards the development of animal-fibre reinforced composites. The economic importance of the cow hair will also be more than the production of felt cushions and shoe brushes which are major crafts in northern Nigeria. The chemicals used for this study were chosen due to their low cost.

\section{Experimental}

\subsection{Materials}

The principal materials utilized for this research were the hairs scraped from the tails of white Fulani cows (Zebu breed) procured from a local abattoir in Akure, Ondo state, SouthWest, Nigeria. The chemicals were procured from Pascal Scientific Akure, Ondo State, Nigeria.

\subsection{Experimental Methods}

\subsubsection{Chemical Treatments of the Cow Hair Fibres}

The cow hair fibres procured from a local abattoir in Ondo State were thoroughly washed with detergents and rinsed with tap water and distilled water ensued by drying at room temperature for 24 hours to remove impurities and blood stains from the fibres. The cleaned fibres were separated into two portions for chemical treatments and controlled experimentations. The fibres to be chemically treated were dipped in containers containing the chemicals of varying molar concentrations of $0.1,0.15$ and $0.2 \mathrm{M}$ for the $\mathrm{H}_{2} \mathrm{O}_{2}(\mathrm{pH}$ $=11), \mathrm{NaOH}(\mathrm{pH}=10)$ and $\mathrm{KOH}(\mathrm{pH}=10)$ treatments respectively. The chemical treatments were placed inside a shaker water bath maintained at $50{ }^{0} \mathrm{C}$ for 4 hours to effectively remove lipids from the surfaces of the fibres in order to improve wettability and interfacial adhesion between the fibres and any matrix material where they may be used. The chemically treated fibres were later rinsed with tap water and distilled water to remove any residual chemicals left on the surfaces of the fibres and this was ensued by sun drying for 5 days.

\subsubsection{Proximate Analysis}

The physicochemical constituents of the cow hair fibres were manually determined using proximate analysis in accordance with AOAC standard (2001) [41]. The crude protein, moisture, and ash contents of the cow hair fibres were evaluated.

\subsubsection{Crude Protein Determination}

This involved three stages namely; digestion, distillation and titration.

\section{(i). Digestion}

About $0.5 \mathrm{~g}$ of sample was weighed into $500 \mathrm{ml}$ kjeldahl flask. Concentrated $\mathrm{H}_{2} \mathrm{SO}_{4}(10 \mathrm{ml})$ and selenium catalyst were added and boiled until the sample turned into clear solution. It was cooled and made up to $50 \mathrm{ml}$ with distilled 
water. The sample was stored in a bottle.

\section{(ii). Distillation}

To carry out distillation, $5 \mathrm{ml}$ of $2 \% \mathrm{H}_{2} \mathrm{BO}_{3}$ (Boric acid) was put into the conical flask and 2 drops of mixed indicator ( $0.198 \mathrm{~g}$ bromocresol green plus $0.132 \mathrm{~g}$ methyl red into 200 $\mathrm{ml}$ alcohol) were added. The receiving flask was positioned so that the tip of the condenser tube was below the surface of the boric acid. The $5 \mathrm{ml}$ of digested sample was pipetted into the condenser's cup and $10 \mathrm{ml}$ of $40 \% \mathrm{NaOH}$ was added. This was then washed down with distilled water. The joints were tightened and distillation was done till a volume of 50 $\mathrm{ml}$ was reached in the receiving flask.

\section{(iii). Titration}

The distillate was titrated with $0.1 \mathrm{ml} \mathrm{HCl}$ until the end point (pink colour) was reached.

$\%$ Nitrogen $=\frac{\text { Titre Value } X 0.1 \mathrm{M} \mathrm{HCl} \times 0.014 \times 100 \times \frac{V_{1}}{V_{2}} \times 100}{\text { Weight of Sample }}$

Where,

$\mathrm{V}_{1}=$ volume of digest $(50 \mathrm{ml})$

$\mathrm{V}_{2}=$ volume of digest used $(5 \mathrm{ml})$ and

$\%$ Crude protein $=\%$ Nitrogen $x 625$

\section{(iv). Moisture Content Determination}

This was done using the oven-drying method. Cleaned, dry and well-labeled petri dishes were weighed $\left(\mathrm{W}_{1}\right)$. About $5 \mathrm{~g}$ of each sample were weighed into the dishes $\left(\mathrm{W}_{2}\right)$ and transferred into the oven maintained at $105{ }^{\circ} \mathrm{C}$ for 3 hours. After the three hours, they were transferred into the desiccators to cool and then weighed $\left(\mathrm{W}_{3}\right)$. This process was continued every hour until a constant weight was obtained.

$$
\% \text { Moisture }=\frac{\text { Loss in Weight of Sample }\left(W_{3}-W_{2}\right) \times 100}{\text { Weight of Samples before drying }\left(W_{2}-W_{1}\right)}
$$

\section{(v). Ash Content Determination}

Dry and clean crucibles were weighed $\left(\mathrm{W}_{1}\right)$ and their respective weights recorded and, about $1 \mathrm{~g}$ of the samples was added and weighed again $\left(\mathrm{W}_{2}\right)$. The crucibles and contents were placed into the muffle furnace at $600{ }^{\circ} \mathrm{C}$ until a light grey colour of ash was obtained. The crucibles were removed and allowed to cool in the desiccators and then weighed $\left(\mathrm{W}_{3}\right)$

$$
\% \text { Ash }=\frac{\text { Weight of Ash }\left(W_{2}-W_{3}\right) \times 100}{\text { Weight of Sample }\left(W_{2}-W_{1}\right)}
$$

To ensure accuracy and reliability of test results, the analyses were replicated twice.

\subsubsection{Tensile Testing}

The tensile properties of the cow hair fibres were evaluated with the aid of an INSTRON 1195 universal testing machine at a fixed crosshead speed of $10 \mathrm{mmmin}^{-1}$ at a temperature of $25 \pm 2{ }^{\circ} \mathrm{C}$. The test samples were prepared according to ASTM D412-83 [42]. The computer automatically generates the required data and graphs as the tests are being carried out. To ensure accuracy and reliability of tensile test results, three repeatability tests were performed for each determined tensile property of the cow hair fibres.

\section{Results and Discussion}

\subsection{Physicochemical Properties}

\subsubsection{Crude Protein Content}

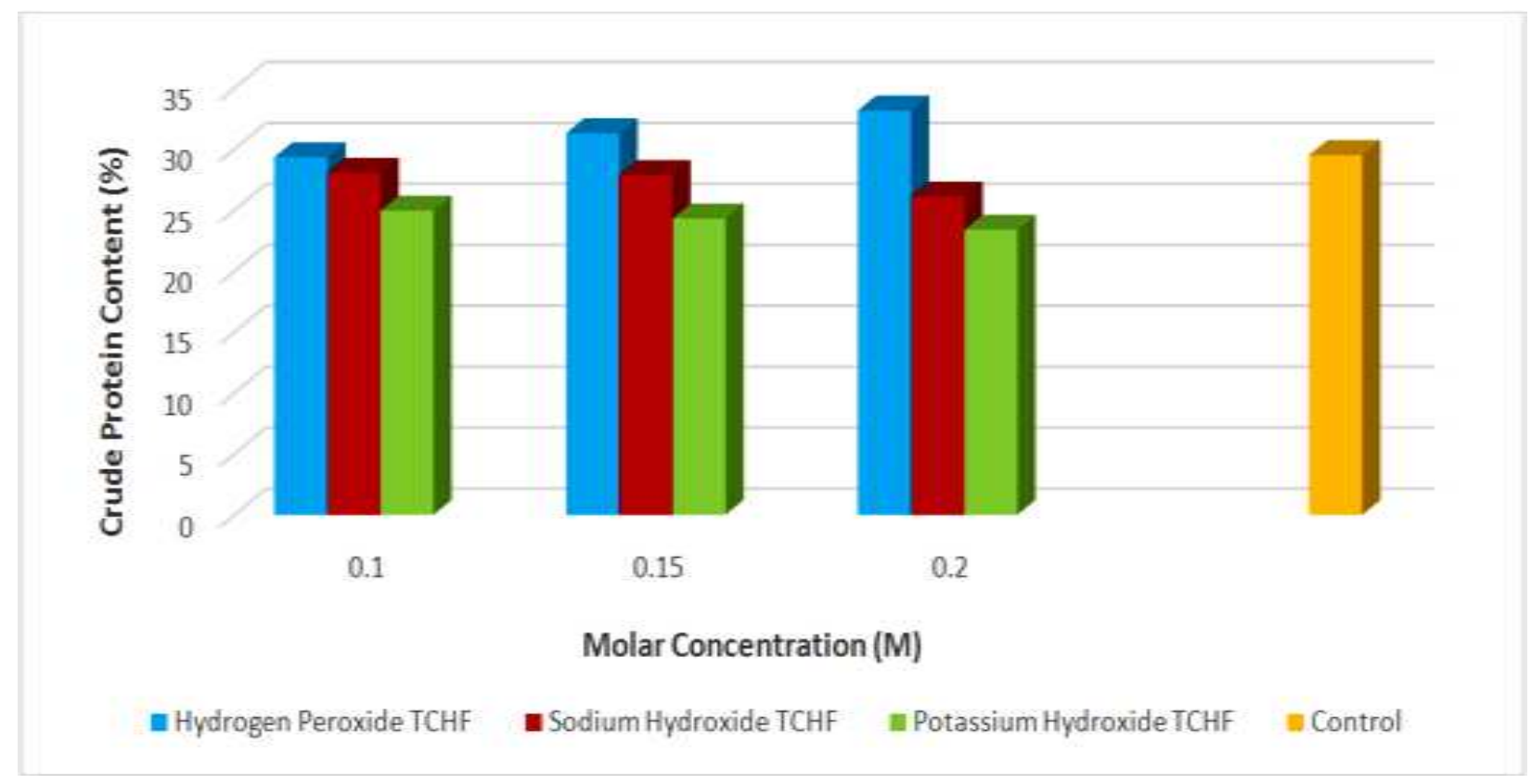

Figure 1. Variation of crude protein content with molar concentrations of the chemical treatments for the cow hair fibres.

The variation of crude protein content with molar concentrations of the chemical treatments for the cow hair fibres is presented in Figure 1 above. The results revealed that there is a progressive increase in the crude protein 
content of the $\mathrm{H}_{2} \mathrm{O}_{2}$ treated cow hair fibres (TCHF) with increase in molar concentration and a regression was observed in the case of the $\mathrm{NaOH}$ and $\mathrm{KOH}$ TCHFs respectively. The cow hair fibre $(\mathrm{CHF})$ treated with $0.2 \mathrm{M}$ $\mathrm{H}_{2} \mathrm{O}_{2}$ gave the superlative result in terms of crude protein content while the CHF treated with $0.2 \mathrm{M} \mathrm{KOH}$ gave the least enhancement. Of all the chemical treatments, only the CHFs treated with 0.15 and $0.2 \mathrm{M} \mathrm{H}_{2} \mathrm{O}_{2}$ have crude protein contents that are higher than that of the control test sample i.e. the untreated CHF. Goud et al (2011) in their investigation on the effect of $\mathrm{H}_{2} \mathrm{O}_{2}$ treatment on protein content and catalase activity in Cajanuscajan (L.) Millsp leaves reported a similar progressive trend in the protein content of the leaves with lower molar concentrations of $\mathrm{H}_{2} \mathrm{O}_{2}$ treatment [43]. According to Wolfram et al (1970) the perhydroxy anion $\left(\mathrm{HO}_{2}-\right)$ is the predominant reactive species during $\mathrm{H}_{2} \mathrm{O}_{2}$ treatment of hair fibres. The abundance of sites in hair keratin which might yield to a nucleophilic attack by this ion precludes any firm prior assignment of a specific interaction. The reaction between keratin and $\mathrm{H}_{2} \mathrm{O}_{2}$ is confined mainly to the cysteine residues. The decrease in cysteine is almost quantitatively matched by a corresponding increase in cysteic acid [44]. The work of Robbins (2012) has also shown that the primary chemical differences between $\mathrm{H}_{2} \mathrm{O}_{2}$ treated hair and unaltered hair are lower cystine content, a higher cysteic acid content, and lower amounts of tyrosine and methionine in the treated hair. He said these results support Zahn's original conclusion that the reaction of $\mathrm{H}_{2} \mathrm{O}_{2}$ with human hair protein occurs primarily at the disulfide bonds. Fewer total micromoles of amino acids per gram of hair are found in treated hair than in unaltered hair most likely because of addition of oxygen to the sulfur containing amino acids and the solubilization of protein or protein derived species into the treatment bath [45]. The result of this study revealed that it is possible that the increase in the molar concentration of $\mathrm{H}_{2} \mathrm{O}_{2}$ facilitated the formation of more amino acids from the oxidation of sulfhydryl $(-\mathrm{SH})$ groups contained in the keratin of the CHFs hence, increase in the crude protein content. Also, the underlying chemistry behind the regression observed in the crude protein content of the CHFs treated with $\mathrm{NaOH}$ and $\mathrm{KOH}$ treatments can be seen in the work of Ameen et al (2014) when they treated Jatrophacurcas leaf with $\mathrm{NaOH}$. They attributed this occurrence to possible loss of some amino acids in the fibres due to high concentration of the alkaline treatment. These amino acids are released into the treatment bath as the polypeptide bonds are broken down by the potassium or sodium hydroxide during alkaline treatment of the fibres [46]. Alkaline hydrolysis generates sodium and/or potassium salts of free amino acids; oligopeptides (small chains of amino acids) are also generated as intermediates in the reaction. Some amino acids, such as arginine, asparagine, glutamine, and serine, are destroyed, while others are racemized; i.e., the molecules are structurally modified from a left-handed configuration to a mixture of left-handed and right-handed molecules [47].

\subsubsection{Moisture Content}

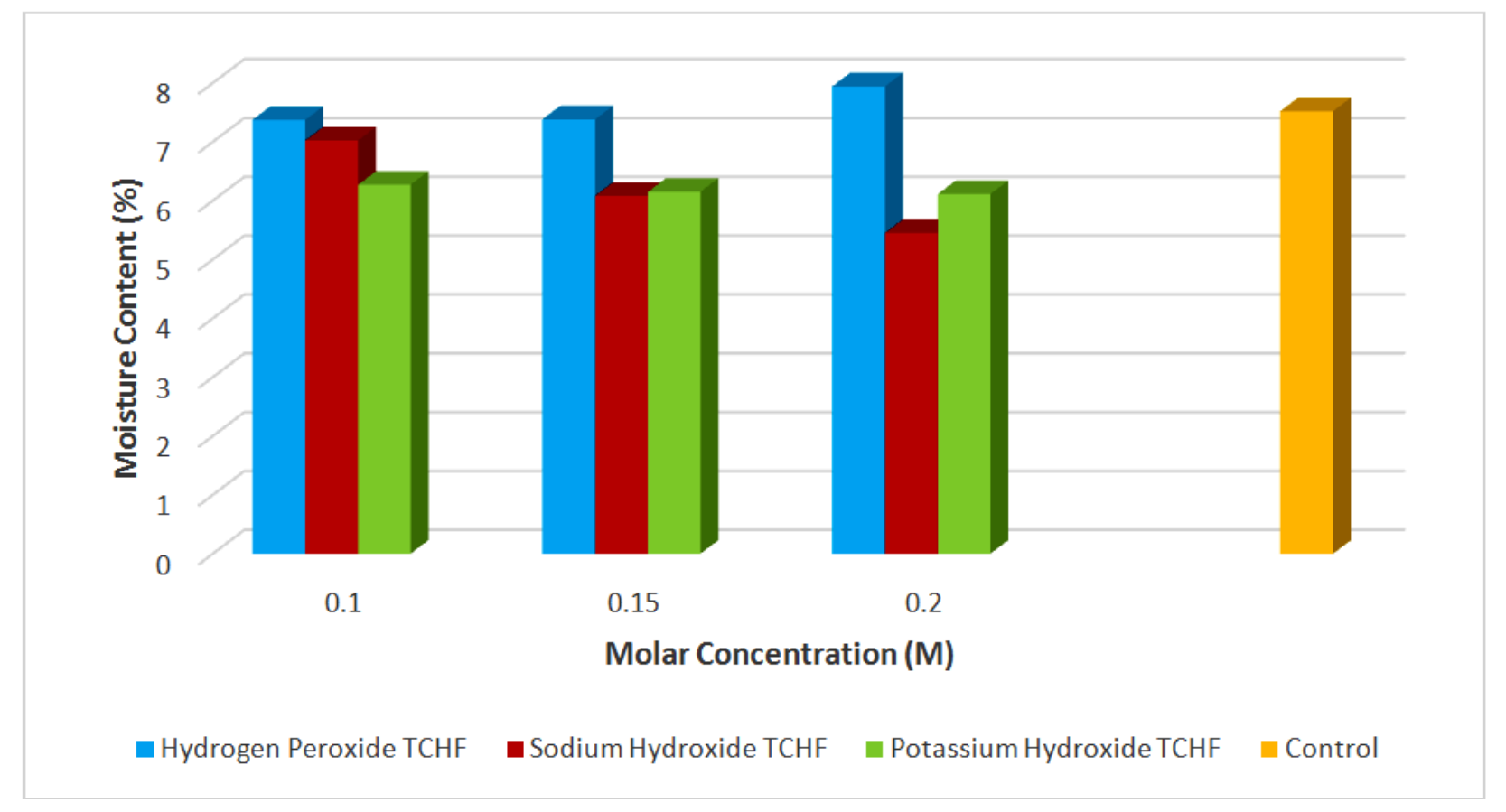

Figure 2. Variation of moisture content with molar concentrations of the chemical treatments for the cow hair fibres.

The variation of moisture content with molar concentrations of the chemical treatments for the CHFs is presented in Figure 2 above. The result revealed a progression in the moisture content of the $\mathrm{H}_{2} \mathrm{O}_{2}$ TCHFs with increase in the molar concentration of the $\mathrm{H}_{2} \mathrm{O}_{2}$ treatment. This is a clear indication that the chemical treatment was effective enough in removing the lipids and other hydrophobic layers covalently bonded to the surface of the 
CHF thereby exposing its hydrophilic cortex which in turn resulted in increase in water absorption capacity of the $\mathrm{H}_{2} \mathrm{O}_{2}$ TCHFs [47] and this increased with increase in molar concentration, oxidative treatment such as hydrogen peroxide treatment have been reported by Baghdadli and Luengo, (2008) to increase the hydrophilic character of hair [48]. For the $\mathrm{NaOH}$ and $\mathrm{KOH}$ treatments, a reduction in moisture content with increase in molar concentration was observed in the CHFs. The treatments possibly rendered the cow hair fibres more hydrophobic by depositing hydrophobic coatings formed during the treatment on the surfaces of the CHFs thereby reducing the chances of exposing the hydrophilic cortex and this increased with increase in molar concentration, hence reduction in water absorption capacity of the CHFs which accounted for the reduction in mositure content of the $\mathrm{KOH}$ and $\mathrm{NaOH}$ TCHFs. Also the reduction in the moisture content of the $\mathrm{NaOH}$ and $\mathrm{KOH}$ TCHFs can be attriuted to the reduction of the hyrophilic hydroxyl groups within the fibre structure caused by the chemical reducing potential of the $\mathrm{KOH}$ and $\mathrm{NaOH}$ treatments which can break down the alkali sensitive hydroxyl groups present within the structure of the CHFs, this reaction drives out water molecules from the fibre structure and hence reduction in the hydrophilic power of the CHFs [49]. A glaring consistent trend in mositure reduction with increase in molar concentration was observed with the $\mathrm{NaOH}$ TCHFs and for the $\mathrm{KOH}$ TCHFs the reduction in moisture content with increase in molar concentration is almost negligible. The 0.2 $\mathrm{M} \mathrm{H}_{2} \mathrm{O}_{2}$ TCHF has the highest moisture content in comparison with all the other test samples while the least moisture content is given by the $0.2 \mathrm{M} \mathrm{NaOH}$ TCHF. Only the 0.2 and $0.15 \mathrm{M} \mathrm{H}_{2} \mathrm{O}_{2}$ TCHFs have higher mositure contents than the untreated $\mathrm{CHF}$.

\subsubsection{Ash Content}

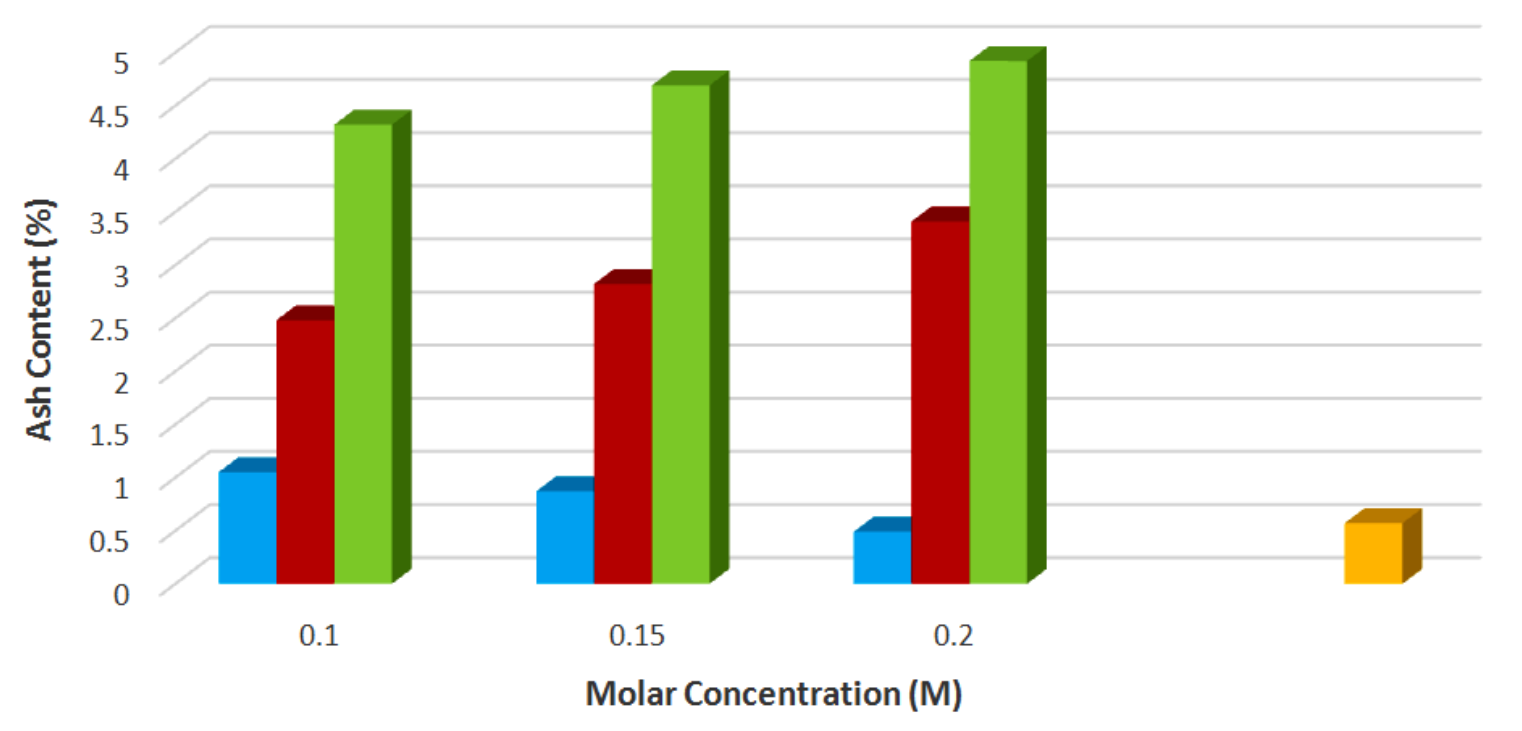

घydrogen Peroxide TCHF $\quad$ Sodium Hydroxide TCHF $\quad$ - Potassium Hydroxide TCHF $\quad$ Control

Figure 3. Variation of ash content with molar concentrations of the chemical treatments for the cow hair fibres.

In Figure 3 above, the variation of ash content with molar concentrations of the chemical treatments for the CHFs is presented. The results revealed a decrease in the level of ash content with increase in molar concentrations of the $\mathrm{H}_{2} \mathrm{O}_{2}$ treatment. The lowest level of ash content was observed in the $0.2 \mathrm{M} \mathrm{H}_{2} \mathrm{O}_{2}$ TCHF which is also the only sample with ash content lower than that of the control sample. The result showed that the optimum molar concentration of chemical treatment for reducing ash content of the hair fibre is $0.2 \mathrm{M}$ $\mathrm{H}_{2} \mathrm{O}_{2}$. Considering $\mathrm{NaOH}$ and $\mathrm{KOH}$ treatments, the results showed a progressive increase in the ash contents for the CHFs with increase in molar concentrations. The results also revealed that for each molar concentration, the KOH TCHFs showed higher ash contents than the $\mathrm{NaOH}$ TCHFs. Some researchers have been able to identify that the ash content of cattle hair contains the following element: boron, barium, calcium, copper, iron, lead, potassium, magnesium, manganese, phosphorus, silicon, silver, sodium and zinc [50].

\subsection{Tensile Properties}

\subsubsection{Tensile Strength at Maximum Load}

The variation of tensile strength at maximum load with molar concentrations of the chemical treatments for the CHFs is presented in Figure 4 below. The result showed a progressive increase in the ultimate tensile strengths of the $\mathrm{H}_{2} \mathrm{O}_{2}$ TCHFs with increase in molar concentration and an inconsistent trend was observed with the $\mathrm{KOH}$ and $\mathrm{NaOH}$ TCHFs. However, the ultimate tensile strengths of all the chemically treated samples were significantly enhanced, with the $0.2 \mathrm{M} \mathrm{H}_{2} \mathrm{O}_{2}$ TCHF having the superlative performance 
with a tensile stress at maximum load which is $57.15 \%$ better than the untreated $\mathrm{CHF}$ and the $0.15 \mathrm{M} \mathrm{NaOH}$ TCHF having the lowest value which is still $36.57 \%$ better than the untreated $\mathrm{CHF}$. With respect to the $\mathrm{KOH}$ treatment the optimum result is given at $0.1 \mathrm{M}$ while the optimum result for the $\mathrm{NaOH}$ treatment is at $0.2 \mathrm{M}$. This is a clear indication that the basic hydrolysis of the cortex keratin of the CHFs by the $\mathrm{KOH}$ and $\mathrm{NaOH}$ treatments and the solubilization of the cortex keratin of the CHFs by the oxidative $\mathrm{H}_{2} \mathrm{O}_{2}$ treatment at $50{ }^{\circ} \mathrm{C}$ for 4 hours resulted in an improved structural integrity of the cortical keratin of the chemically treated CHFs, hence improved plasticity of the TCHFs under tensile loading. It is available in existing literatures that the mechanical behavior of hair fibre is fundamentally dependent on the orderliness of the structure of hair cortex [51]. Also the improvement in the ultimate tensile strength of the TCHFs might be due to the breaking of the covalent bonds between the lipids and the surfaces of the CHFs leaving a stronger and stiffer fibre which in turn also improved the maximum stress the TCHFs can sustain under tensile loading. Rosa et al (2009) investigated the effect of chemical treatment on coir fibers and the report about their research findings revealed that alkali treatment was able to improve the tensile strength of the coir fibres which is in agreement with the result of this present study [52].The superlative performance is observed with the $0.2 \mathrm{M} \mathrm{H}_{2} \mathrm{O}_{2} \mathrm{TCHF}$.

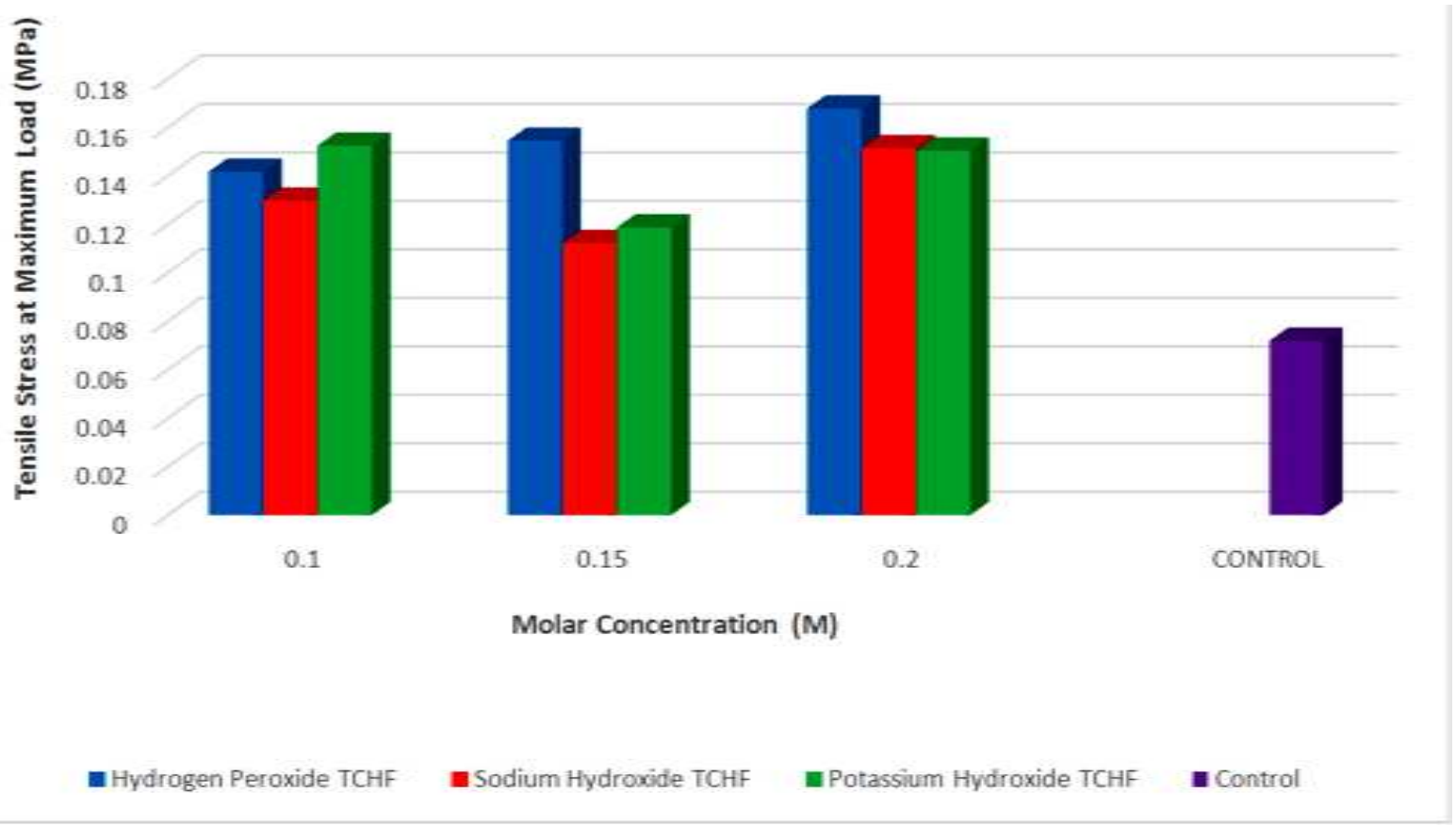

Figure 2. Variation of tensile strength at maximum load with molar concentrations of the chemical treatments for the cow hair fibres.

\subsubsection{Tensile Stress at Yield}

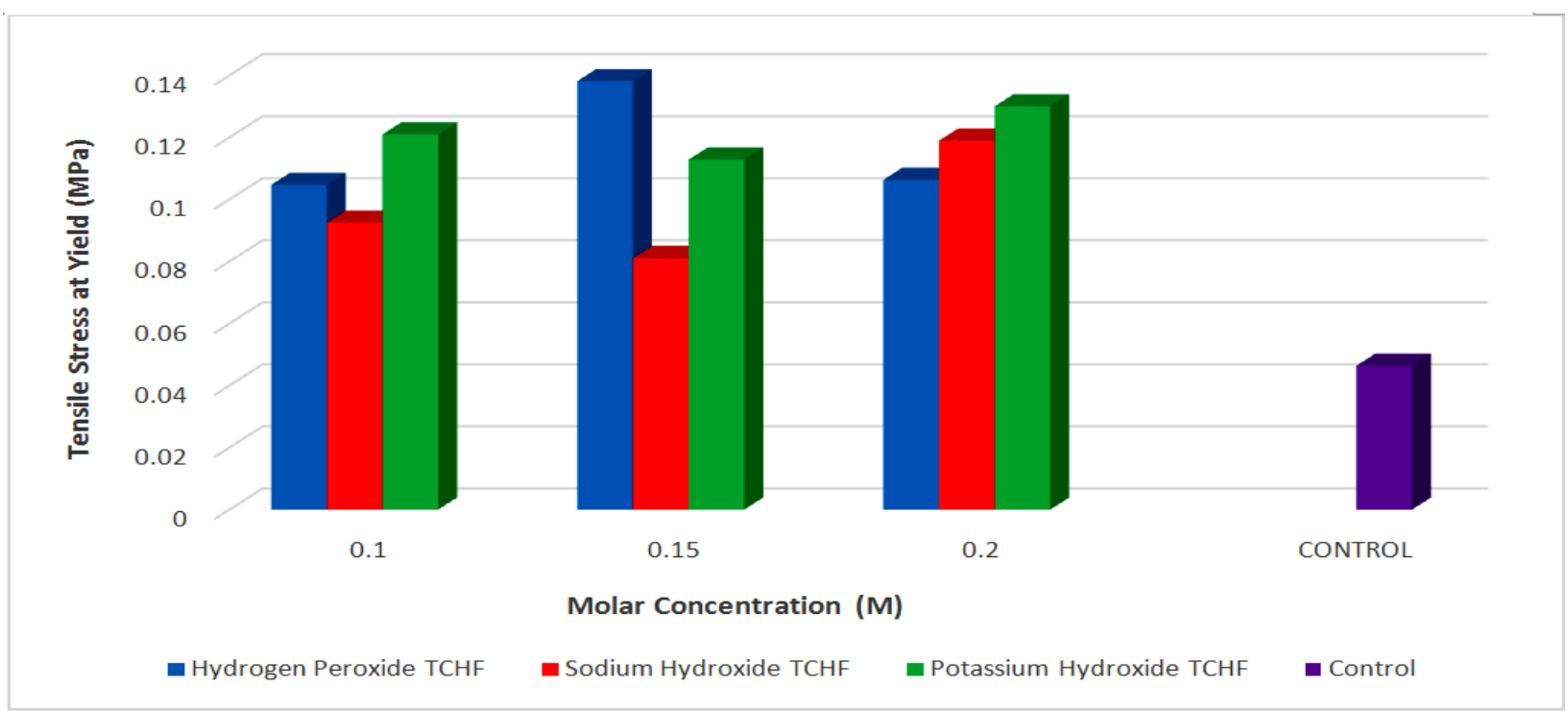

Figure 3. Variation of tensile stress at yield with molar concentrations of the chemical treatments for the cow hair fibres. 
Figure 5 above shows the variation of tensile stress at yield with molar concentrations of the chemical treatments for the CHFs. Observations from this result revealed an inconsistency in the trends of all the TCHFs with respect to increase in molar concentration and tensile stress at yield. Similarly, as observed in Figure 4, all the chemically TCHFs gave better tensile stress at yield in comparison with the untreated CHF. The superlative performance of the results can be seen with the $0.15 \mathrm{M} \mathrm{H}_{2} \mathrm{O}_{2}$ TCHF which has a yield strength that supersedes that of the untreated CHF by $66.43 \%$ and the least enhancement in yield strength is observed with the $0.15 \mathrm{M} \mathrm{NaOH}$ TCHF which is still better than the untreated $\mathrm{CHF}$ by $42.77 \%$. The result also revealed that the optimum performance with respect to the $\mathrm{KOH}$ and $\mathrm{NaOH}$ treatments is at $0.2 \mathrm{M}$. This is a clear indication that thermochemical treatments was able to reduce the strength of the chemical bonds such as cystine, hydrogen and salt bonds in the TCHFs, hence improvement in their elastic behaviour. These various chemical bonds have been reported by McKay (2015) to be responsible for holding strands of protein (in this case, the strands of the cortical keratin) in the hair fibre together [53].

\subsubsection{Tensile Strain at Break}

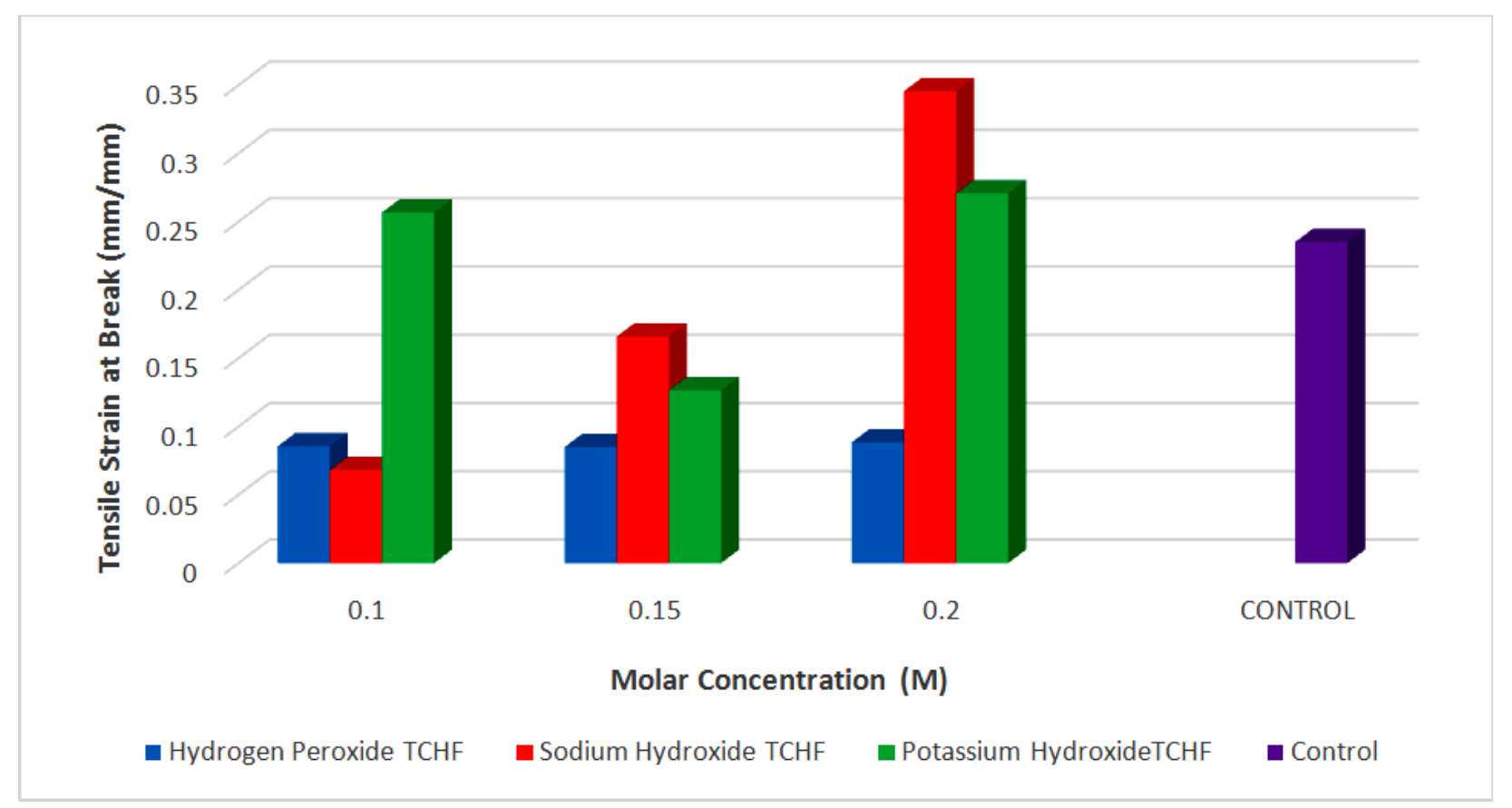

Figure 4. Variation of tensile strain at break with molar concentrations of the chemical treatments for the cow hair fibres.

The variation of tensile strain at break with molar concentrations of the chemical treatments for the CHFs is presented in Figure 6 above. Observations made from the results revealed that, the effect of $\mathrm{H}_{2} \mathrm{O}_{2}$ treatment on the $\mathrm{CHFs}$ irrespective of molar concentration did not enhance the elongation at break of the CHFs; however, increase in molar concentration did not affect the tensile strain at break of the $\mathrm{H}_{2} \mathrm{O}_{2}$ TCHFs. There appears to be a constant tensile strain at break of about $0.085 \pm 0.003 \%$ for all the $\mathrm{H}_{2} \mathrm{O}_{2}$ TCHFs. For the $\mathrm{NaOH}$ TCHFs a progressive increase in tensile strain at break with increasing molar concentration was observed with the $0.2 \mathrm{M} \mathrm{NaOH}$ TCHF giving the best value of elongation before failure which supersedes that of the untreated CHF by $31.94 \%$. As for the KOH TCHFs there was no consistency in the trend of increasing molar concentration with tensile strain at break. However, the optimum tensile strain at break with the $\mathrm{KOH}$ treatment is given at $0.2 \mathrm{M}$. According to some authors, it is expected that increase in the yield strength of a material is very likely to bring about decrease in the ductility of the material [54] which is what is apparent with most of the chemically TCHFs in this present study, notwithstanding the $0.1,0.2 \mathrm{M} \mathrm{KOH}$ and the $0.2 \mathrm{M} \mathrm{NaOH}$ TCHFs demonstrated exceptional behaviours.

\section{Conclusions}

This work has been carried out in order to further encourage the use of natural fibres, particularly animal fibres which have not been extensively exploited as their vegetal counterparts for engineering applications and also to promote the selection of renewable ecofriendly materials for composites development; thereby adding value to what is otherwise regarded to as wastes. From the research findings, it was observed that:

- Chemical treatments is suitable for the modification and enhancement of the physicochemical and hence, the tensile properties of animal fibres. This was the case because in all the properties examined, it was observed that, chemically treated cow hair fibres gave the best results.

- Among the selected chemicals used, $\mathrm{H}_{2} \mathrm{O}_{2}$ was observed to be the best followed by $\mathrm{NaOH}$ and $\mathrm{KOH}$ respectively. 
The results revealed that $\mathrm{H}_{2} \mathrm{O}_{2}$ treatment is always at variance with the $\mathrm{NaOH}$ and $\mathrm{KOH}$ treatments.

- The use of higher concentration of the chemicals between 0.15-0.2 $\mathrm{M}$ aids the best enhancement of the investigated properties.

\section{References}

[1] M.P. Groover, Fundamentals of Modern Manufacturing, Materials, Processes and Synthesis, 4th Edition, John Wiley and Sons, INC, Danvers, United State of America, (2010) pp. 306, 698-700.

[2] H.F. El-Labban, M. Abdelaziz, E.R.I Mahmoud, Modification of Carbon Steel by Laser Surface Melting: Part II: Effect of Laser Beam Power on Microstructural Features and Surface Hardness, American Journal of Engineering and Applied Sciences, 6 (4): (2014) pp. 384-392.

[3] B. Kuriachen, K.P. Somashekhar, J. Matthew, Multiresponse Optimization of Micro-wire Electrical Discharge Machining Process, International Journal of Advanced Manufacturing Technology, 76: (2015) pp. 91-104.

[4] J.C. Shaw, H. Zhou, Y. Chen, N.O. Weiss, Y. Liu, Y. Huang, X. Duan, Chemical Vapor Deposition Growth of Monolayer MoSe2Nanosheets, Nano Research, Tsinghua University Press and Springer-Verlag Berlin Heidelberg (2014) pp. 2-6.

[5] M. Fathi, T. Zarede, M. Ayad, M. Abderrazak, Application of Thin Films and Nanotechnology for Improving the Performance of Solar Energy Systems in the Desert Climate Conditions, Int'l Conference on Artificial Intelligence, Energy and Manufacturing Engineering, June 9-10, Kuala Lumpur Malaysia, (2014) pp. 51-54.

[6] M.J. Lieser, J. Xu, Composites and the Future of Society: Preventing a Legacy of Costly Corrosion with Modern Materials, Owens Corning, Innovation for Living, (2010) pp. 13-15.

[7] C. Leyens, M. Peters, Aerospace and Materials, Materials Science and Engineering, Vol. III, (2003) pp. 3-6.

[8] B. Bell, Materials Intelligence: An Overview of New Materials for Manufactures, FPInnovations, (2011) pp. 7-12.

[9] C. Popescu, H. Iancau, L. Hancu, A. Crai, A Study Regarding the Mechanical Behavior of Polymeric Composites at Cryogenic Temperature, Annals of the University of Craiova, Electrical Engineering Series, No. 32,(2008) pp. 346-350.

[10] E. Wuchina, E. Opila, M. Opeka, W. Fahrenholtz, I. Talmy,UHTCs: Ultra-High Temperature Ceramic Materials for Extreme Environment Applications, the Electrochemical Society Interface, (2007) pp. 30-35.

[11] V.N. Haruna, A.S. Abdulrahman, P.T. Zubairu, L.O. Isezuo, M.A. Abdulrahman, D.C. Onuoha, Prospects and Challenges of Composites in a Developing Country, ARPN Journal of Engineering and Applied Sciences, Vol. 9, No. 7, (2014) pp. 1069-1071.

[12] M. Ashby, K. Johnson, Materials and Design: The Art and Science of Material Selection in Product Design, Second Edition, Butterworth-Heinemann, Oxford, United Kingdom, (2010) pp. 14-25.
[13] H.A. Abba, I.Z. Nur, S.M. Salit, Review of Agro Waste Plastic Composites Production, Journal of Minerals and Materials Characterization and Engineering, Vol.1, No.5, (2013) pp. 271-279.

[14] J. Sahari, S.M. Sapaun, Natural Fibre Reinforced Biodegradable Polymer Composites, Reviews on Advanced Materials Science, 30, (2011) pp. 166-174.

[15] N.A. Anthony, Evaluation of Mechanical Properties of Polyester Matrix Reinforced With Bamboo Fibre for the Production of Low Strength Building Products, International Journal of Engineering and Applied Sciences, Vol. 2, No. 2, (2013) pp. 57-65.

[16] K.B. Jagadeeshgouda, P.R. Reddy, K. Ishwaraprasad, Experimental Study of Behaviour of Poultry Feather Fiber: A Reinforcing Material for Composites, International Journal of Research in Engineering and Technology, (2014) pp. 363-371.

[17] J.P. Dhal, S.C. Mishra, Processing and Properties of Natural Fiber-Reinforced Polymer Composite, Journal of Materials Science, (2013) pp. 4-5.

[18] J.B. Rao, D.V. Rao, N.R.M.R, Bhargava, Development of Light Weight ALFA Composites, International Journal of Engineering, Science and Technology Vol. 2, No. 11, (2010) pp. 55-58.

[19] J.A.K. Gladston, N.M. Sherrif, I. Dinaharan, J.D.R. Selvam, Production and Characterization of Rich Husk Ash Particulate Reinforced AA6061 Aluminum Alloy Composites by Compocasting, Transactions of NonFerrous Metals Society of China, Vol. 25, No. 3 (2015).

[20] M.A. Masuelli, Introduction of Fibre-Reinforced Polymers Polymers and Composites: Concepts, Properties and Processes, Intech, Chapter 1, (2011).

[21] W.D. Callister, D.G. Rethwisch, Fundamentals of Materials Science and Engineering, An Integrated Approach, Third Edition, John Wiley and Sons, INC, Asia, Chapter 1, (2008) pp 5-13.

[22] D. Jain, A. Kothari, Hair Fibre Reinforced Concrete, Recent Journal of Recent Sciences, Vol. 1, (2012) pp. 128-133.

[23] U.G. Tomas, Effects of Human Hair Additives in Compressive Strength of Asphalt Cement Mixture, International Journal of Advanced Science and Technology Vol.67, (2014) pp.11-22.

[24] B.R. George, A. Bockarie, H. McBride, D. Hoppy, A. Scutti, Utilization of Turkey Feather Fibers in Nonwoven Erosion Control Fabrics, INJ Summer, (2003) pp. 45-50.

[25] E. Dirgar, O. Oral, Yarn and Fabric Production from Angora Rabbit Fiber and Its End-Uses, American Journal of Materials Engineering and Technology, 2014, Vol. 2, No. 2, (2014) pp. 26-28.

[26] K. Adam, Natural Fibres, retrieved from http://www.naturalfibres2009.org/en/fibres/ on 20-04-2015.

[27] E.T. Moran, J.D. Summers, Processing of Tannery By-Product Cattle Hair into a Nutritionally Available High Protein Meal: Metabolizable Energy, Amino Acid Composition and Utilization In Practical Diets By The Chick Department of Poultry Science, University of Guelph, Guelph, Ontario, Canada (2009). 
[28] I. Khan, E. Maldonado, V. Vasconcelos, S.J. O’Brien, W.E. Johnson, A. Antunes, Mammalian Keratin Associated Proteins (Krtaps) Subgenomes: Disentangling Hair Diversity and Adaptation to Terrestrial And Aquatic Environments, BMC Genomics, 15:779, (2014) pp. 2-5.

[29] I.O. Oladele, J.A. Omotoyimbo, S.H. Ayemidejo, Mechanical Properties of Chicken Feather and Cow Hair Fibre Reinforced High Density Polyethylene Composites. International Journal of Science and Technology Volume 3 No. 1, (2014) pp. 66-71.

[30] I.O. Oladele, J.L. Olajide, A.S. Ogunbadejo, The Influence of Chemical Treatment on the Mechanical Behaviour of Animal Fibre-Reinforced High Density Polyethylene Composites, American Journal of Engineering Research, Vol. 04, Issue 02, (2015) pp. 19-26.

[31] G. Motsanos, Advantages of Natural-fibre Applications using BioHybrid Composites, retrieved from $\mathrm{http}: / /$ www.jeccomposites.com/news/compositesnews/advantages-natural-fibre-applications-using-biohybridcomposites on 15-04-2015.

[32] S. Parveen, S. Rana, Raul Fangueiro, Natural Fiber Composites for Structural Applications, Mechanics of Nano, Micro and Macro Composite Structures Politecnico di Torino, (2012).

[33] M.M. Kabir, H. Wang, K.T. Lau, F. Cardona, Natural Materials in Composites Engineering, Chemical treatments on Plant-based Natural Fibre-reinforced Polymer Composites: An Overview, Composites Part B: Engineering Volume 43, Issue 7, (2012) pp. 2883-2892.

[34] M. Huda, W. Schmidt, M. Misra, L. T. Drzal, Effect of Fiber Surface Treatment of Poultry Feather Fibers on the Properties of Their Polymer Matrix Composites Journal of Applied Polymer Science, Volume 128, Issue 2, (2013) pp.1117-1124.

[35] A. Lakshmanan, Finishing of Angora Rabbit Fibers, American Journal of Materials Engineering and Technology, Vol. 2, No. 2, (2014) pp. 20-25.

[36] O.A. Lawal-Adebowale, Dynamics of Ruminant Livestock Management in the Context of the Nigerian Agricultural System, Chapter 4, Agricultural and Biological Sciences, Livestock Production, intech, (2012) pp. 61-74.

[37] A.O.K, Adesehinwa, J.O. Okunola, M.K. Adewumi, Socioeconomic Characteristics of Ruminant Livestock Farmers and their Production Constraints in Some Parts of South-Western Nigerian. Livestock Research for Rural Development, 16 (8) (2004).

[38] http://gemsnigeria.com/wordpress/wpcontent/uploads/2012/12 /GEMS1MidiBrief_LeatherIndustryTransformation-8Page.pdf Retrieved on 20-04-2015.

[39] K. Ekenma, N. J.Anelon, A. A.Ottah, Determination of the presence and concentration of heavy metals in cattle hides singed in Nsukka Abattoirs, Journal of Veterinary Medicine and Animal Health pp. Vol. 7 (1) (2015) pp 9-14.

[40] W.Y. Akwetey, D.C. Eremong, A. Donkoh A, Chemical and Nutrient Composition of Cattle Hide ("Welle") using Different Processing Methods, Journal of Animal Science Advances 3 (4), (2013) pp. 176-180.
[41] AOAC International Official Method of Analysis996-06, revised 2001, in Official Methods of Analysis, 18th edition: AOAC International, Gaithersburg, MD, (2001).

[42] ASTM. 1983, "Standard Test Methods for Rubber Properties in Tension", Designation D412-83, American Society for Testing and Materials, Philadelphia, PA, (1983).

[43] P.B. Goud , M.S. Kachole, Effect of Exogenous Hydrogen Peroxide on Peroxidase and Polyphenoloxidase Activities in Cajanus cajan (L.) Millsp. Detached Leaves, International Journal of Current Research Vol. 3, Issue, 10, (2011) pp. 061065 .

[44] L. J. Wolfram, K. Hall, I. Hui, The Mechanism of Hair Bleaching, Journal of the Society of Cosmetic Chemists, 21, (1970) pp. 875-900.

[45] C.R. Robbins, Chemical and Physical Behavior of Human Hair, Chapter 2, Springer-Verlag Berlin Heidelberg,(2012) pp. 105-120.

[46] O.M. Ameen, L.A. Usman, N.O. Muhammed, O.F. Okeola, E.O. Boluwarin, O.O. Fadeyi, Effect of Heat and Alkaline Hydrolysis on the Amino Acid Profile of Jatropha Curcas Seed Cake, African Journal of Food, Agriculture, Nutrition and Development, Vol. 14, No. 2, (2014) pp. 2-10.

[47] A. L. Horvath, Solubility of Structurally Complicated Materials: 3.Hair, The Scientific World Journal 9, (2009) pp. 255-271.

[48] N. Baghdadli, G.S. Luengo, A Closer Look at the Complex Hydrophilic/Hydrophobic Interactions Forces at the Human Hair Surface, Journal of Physics: Conference Series 100 (2008) 052034 .

[49] M.J. John, R.D. Anandjiwala, Recent Developments in Chemical Modification and Characterization of Natural FibreReinforced Composites, Polym Compos 29(2): (2008) pp. 187-207.

[50] R.G. Washburn, L.O. Gilmore, N.S. Fechheimer, The Chemical Composition of Cattle Hair. I, The Fat, Ash and Nitrogen Content, The Ohio Journal of Science. v58n3 (1958) pp. 150-152.

[51] M.F. Rosa, B. Chiou , E.S. Medeiros, D.F. Wood, T.G. Williams, L.H.C. Mattoso, W.J. Orts, S.H. Imam, Effect of Fiber Treatments on Tensile and Thermal Properties of Starch/Ethylene Vinyl Alcohol Copolymers/Coir Biocomposites, Bioresource Technology 100, (2009) pp. 5196-5202.

[52] M. V. R. Velasco, T. C. S. Dias, A. Z. Freitas, N. D. Vieira Júnior, C. A. S. O. Pinto, T. M. Kaneko, A. R. Baby, Hair Fiber Characteristics and Methods to Evaluate Hair Physical and Mechanical Properties, Brazilian Journal of Pharmaceutical Sciences, Vol. 45, No. 1, (2009). pp. 154-157.

[53] T. McKay, Elasticity and Healthy Hair,http://www.naturallycurly.com/curlreading/wavy-hairtype-2/elasticity-and-healthy-hair/ retrieved on 20-04-2015.

[54] W.D. Callister, Materials Science and Engineering: An Introduction, 7th Edition, John Wiley and Sons, New York, United States of America, (2007). pp. 144-150. 